La Lepro 44, 4 (1975)

\title{
On the Several Problems of Leprosy Out-patient Treatment in Okinawa
}

\author{
KAZUO SAIKAWA \\ (National Leprosarium, Okinawa Airakuen)
}

\begin{abstract}
In Okinawa Leprosy Out-patient Treatment started in 1962, since then many patients in the field including new patients and escapees from leprosaria have received treatment in leprosy outpatient departments. Moreever early leprosy diagnosis, early treatment, follow-up of discharged patients and contact tracing for house-hold have been strongly performed for thirteen years in O.P.D. The recentry improvement of leprosy epidemiological status in Okinawa is the outcome of leprosy control policy based on out-patient treatment.

The following points should be emphasized to expand leprosy control program there;

1. The major problem in Out-patient care is to ensure regularity of treatment and spacially the priority should be given to the follow-up of Lepromatous and Borderline Leprosy patients.

2. More relapse cases of Lepromatous and Borderline leprosy have been observed than Tuberculoid and Indeterminate leprosy.

3. To prevent relapse the priority should be emphasized to follow-up Lepromatous and Borderline leprosy patients who were discharged from leprosaria.
\end{abstract}

\section{沖繩に於ける攋の外来治療の諸問題}

\author{
犀川 一 夫 \\ （国立療養所沖繩愛楽園）
}

（受付 1975年 9 月 16 日）

\section{沖繩に於ける外来治療の歴史}

沖繩に於て癩の外来治療が初めて実施されたのは, 1960年，石垣市の八重山保健所に於てであった1)。当時 の保健所長大嶺経勝は八重山群島の地域保健対策の一貫 として, 癩検診を実施し, 八重山群島に癩の治療施設の ない所から，非伝染性 $\mathrm{T}$ 型患者を保健所に於て治療管理 した事に始った。癩の有病率, 罹病率の高い八重山群島 に於て, 公衆衛生上必要にせまられた処置ではあった が，世界の新しい瀨管理の動静をいち早く察知したもの として今日高く評価されねばならない。1960年 WHO Leprosy Expert Committee は「癩の Control は公衆
衛生の日常業務に intergate されるべきである22。」と の勧告にそった処置でもあった。1969年沖繩らい予防協 会八重山支部が結成されるや，此の制度は現青山保健所 長に引き継がれ, 沖繩復帰後の今日に至っている。かく して瘷管理の program が保健所の公衆衛生業務に integrate されると云う形式が日本に於てはじめて生れた のである。

一方 1958年, 第 7 回国際瀬学会, 及び WHO 西大平洋 地区の癩 Control に関する会議が東京で開催され，当 時 USCAR の公衆衛生福祉部長 マーシャル大佐が沖繩 より出席, 帰国後沖繩の癩管理は従来の隔離方式を改 め, 外来治療を基本とした治療管理方式で行うべき事を 
第15回沖繩医学会の席上主張した ${ }^{8)}$ 。琉球政府は此の問 題を行政的に如何に取扱うべきか, 当時の日本政府厚生 省に意見を求め，その結果滝沢，難波両技官が来沖，

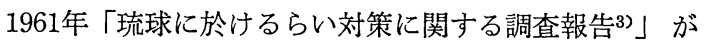
発表された。その中で両技官は沖繩の癩の特殊な状況に かんがみ, 癩の管理方式として外来治療制度を行うべき 事を勧告した ${ }^{3)}$ 。

琉球政府は1961年此の勧告にもとずいて『ハンセン氏 病』予防法を公布し, 㿎の外来治療を公式に制度化する に至った。

次いで1962年政府は外来治療を沖繩らい予防協会に委 託し4)，当協会は那覇市に湊治郎医師の協力を得て実施 にらっした。1972 年 5 月 沖繩の日本復帰にあたって, 『八ンセン氏病』予防法が廃止され，代って日本のらい 予防法が施行された場合の復帰後の外来治療の法的取扱 いについて，諸々論議を呼んだが，当時琉球政府厚生局 の㿎担当専門官を兼務していた著者は, 厚生省, 総理府 と再三協議を重ね, 終に復帰の前1972年 5 月13日に「沖 繩振興開発特別措置法5)」によって法的に復帰後も沖繩 で癩の外来治療を従来通り実施する事がきまり，今日に 及んでいる。

\section{I. 外来治療の意義}

WHO の癩管理に対する政策2)，滝沢，難波レポート 3)にもある様に, 戦後癩の化学療法の進歩に伴い, 癩管 理は従来の隔離管理から, 治療管理に転換され, 癩は外 来治療所（以下 O.P.D と略す）を中心に管理すべきで あると考えられる様になった。外来治療を積極的に進め ると云う考え方には次の理由があげられる。

（1）住民に対する積極的，効果的な感染予防対策とな る。

従来の隔離時代には, 㿎の治療は療養所に入所して初 めて行われていたが実際には隔離を恐れて逃げかくれ し，又家族や職業の都合で入園できず，治療も受けず， かえって感染源になっていた患者が在野にはかなりの数 に及んでいた。癩の外来治療では癩と診断されるや，す ぐ治療が行われる結果, 化学療法による住民一の癩感染 力を低下せしめると共に患者の早期治療にも役立つ。

(2) 瀬管理行政の能率化。

癩患者を隔離方式で管理するに要する経費は，入所患 者の家族援護費を含めないでも, 外来治療の経費に比し て約10倍以上を要するとされ2)，特に多くの在野患者を もつ発展途上国では Man power, 予算の点で隔離方式
で癩の管理を行う事は不可能に近い。

(3) 退所患者の Follow-up と再発防止対策。

療養所からの退所患者のうち, 特にL型, B群患者の 再発を防止するためには，さらに約10年間の Follow-up が必要であると WHO は衔告している ${ }^{6)}$ 事からしても, 此等の患者を O.P.D で引続き管理する事は再発を防止 する点で役立つ。

（4）早期治療の促進。

化学療法の進歩した今日, 癩も一般の疾患の如く診断 と同時に治療が始められるべきものであり, 此の点 O. P.D では癩の早期治療が実施しやすい。

(5) 早期発見の促進。

O.P.D では接触者家族検診が行われやすく又 Skin Clinic では一般皮膚病患者の診療をも行いつつ同時に 癩の早期発見が出来る利点がある。又開業医, 保健所, 一般病院も癩を診断した場合 O.P.D にならば紹介しや すく，医師にとっても，患者にとっても都合が良い。

(6) 癩患者の Rehabilitation, 人間回復の点からも有 利。

患者は O.P.D で社会人として, 職業や家庭を奮われ る事なく治療が出来, 療養所から社会復帰する必要もな く, 患者の Rehabilitation と人間回復と云う点からす ると従来の隔離方式よりすぐれており，かつ人道的でも ある。特に非伝染性患者の治療には最も合理的な方法で ある。

（7）瀬の偏見を取り除くのに有効である。

癩の外来治療制度は癩が一般の病気の様に外来通院で 治療が出来る事を公衆に具体的に示す事になり, 又癩は 特殊な病気でない事を社会人に示し, 偏見を取り除く, よき具体的な事例にもなる。

\section{II. 沖繩に於ける外来治療の特徵}

癩の外来治療に関しては, 琉球政府時代に治療基準が 定められ5)，復帰後もそれにもとずいて実施されてい る。新発生患者を診断した場合, 非伝染性の Case は O.P.D で取り扱ら事にし, 又此処で退園患者の Followup を行う事にしている。それ故に O.P.D では全体と して排菌者は少く, 病型的には $\mathrm{T}$ 型が多くなっている。 又それ故に外国の O.P.D の統計と比較すると, 病型 別, 治癒別, 再発率等の内容にかなりの差が見られる。

患者の症状としては早期の癲が多いので, 本土に比較 すると， L 型， $\mathrm{B}$ 型， $\mathrm{T}$ 型に共通して一様に，病巣が 1 乃至 2 個と云う軽症や, 又 $\mathrm{B}$ 群, I 群の多い事も特徴の 
Tab. 1 The Number of Leprosy Out-patient under Control in Okinawa.

(31 Dec. 1974)

\begin{tabular}{l|r|r|r|r|r|r|r|r|r}
\hline \multirow{2}{*}{ Institute } & \multirow{2}{*}{$\begin{array}{l}\text { No. of } \\
\text { patient }\end{array}$} & \multicolumn{2}{|c|}{ Sex } & \multicolumn{2}{|c|}{ Age } & \multicolumn{4}{c}{ Type } \\
\cline { 4 - 9 } & M & F & $0-14$ & $15+$ & L & T & B & I \\
\hline Naha Skin clinic & 408 & 242 & 166 & 16 & 392 & 186 & 159 & 55 & 8 \\
Miyako Skin clinic & 45 & 25 & 20 & 22 & 23 & 13 & 30 & 2 & 0 \\
Yaeyama Public & 52 & 32 & 20 & 18 & 34 & 11 & 34 & 4 & 3 \\
Health Center & 63 & 37 & 26 & 2 & 61 & 27 & 21 & 14 & 1 \\
O.P.D. in Airakuen & 4 & 3 & 1 & 0 & 4 & 2 & 2 & 0 & 0 \\
O.P.D. in Nanseien & 572 & 339 & 233 & 58 & 514 & 239 & 246 & 75 & 12 \\
\hline \multicolumn{1}{c}{ Total } & & & $(10.1 \%)$ & & $(41.8 \%)$ & $(43.0 \%)$ & $(13.1 \%)$ & $(2.1 \%)$ \\
\hline
\end{tabular}

一つと云え，一口に南方の癩の様相を呈している7)。

\section{III. 沖繩に於ける外来治療の現況}

表 1 は昭和49年12月末現在の沖繩に於ける外来治療患 者の状況を示したもので，T型43\%，B群13.1\%と多い のが注目される。小児は $10 \%$ で近来減少を示している が，性では女性比がかなり高い。

\section{IV. 外来治療制度が沖繩の癩管理に与えた影響}

（1）感染対策に及ぼした影響。

昭和19年頃から，琉球政府の設立された昭和27年頃迄 の沖繩の瀬管理状況は混乱期と云え, 沖繩戦を前にして 日本軍による強制収容，次いで敗戦，占領と続き，癩管 理の不徹底, 療養所運営の困難もあって, その間の愛楽 園の退所患者（逃走, 自己退所患者を含む） は約 413 名 にも及び8), さらに新発生患者も加わり在野にはかなり の患者がいたと推察される。滝沢, 難波レポートはその 数を約 800 名と推定し3，別に USCAR は 1,000名を下 らないと見ていた8)。此の現状をふまえて琉球政府は瀬 の感染源対策及び患者の治療対策として外来治療制度に ふみきらざるを得なかった。沖䌰らい予防協会那覇スキ ンクリニックに於ける年度別の登録患者状況を見ると， 表 2 に示す如く癩の外来治療が社会に浸透するに及ん で，次第に在野患者は O.P.D に集って来た事がわか る。即ち1966年には 148名も登録し，その内 70 名は在野 にいた退所患者を再管理した事になる。

在野患者が隔離, 入園の不安から解き放たれ, 自ら進 んで O.P.D に来て治療を受ける様になった事は社会に 対する感染源対策の上で大きな影響を与えた。此の事は 沖繩の癩の疫学的研究の上で著者がすでに発表した9)如
Tab. 2 Number of Out-patients Registered in Naha Skin Clinic.

(March 1975)

\begin{tabular}{l|r|r|r|r}
\hline & \multicolumn{2}{|c|}{ Number of Registered } & Number of Dis- \\
Year & Total & $\begin{array}{c}\text { Newly- } \\
\text { detected }\end{array}$ & $\begin{array}{c}\text { Discharged } \\
\text { from } \\
\text { Leprosarium }\end{array}$ & $\begin{array}{c}\text { charged from } \\
\text { AIRAKUEN }\end{array}$ \\
\cline { 2 - 5 } 1962 & 14 & 11 & $3(21.4 \%)$ & 82 \\
1963 & 86 & 59 & $27(31.4 \%)$ & 74 \\
1964 & 96 & 57 & $39(40.6 \%)$ & 68 \\
1965 & 122 & 80 & $42(34.4 \%)$ & 48 \\
1966 & 148 & 78 & $70(47.3 \%)$ & 41 \\
1967 & 135 & 85 & $50(37.0 \%)$ & 45 \\
1968 & 139 & 90 & $49(35.3 \%)$ & 52 \\
1969 & 80 & 51 & $27(33.8 \%)$ & 37 \\
1970 & 75 & 42 & $30(40.0 \%)$ & 34 \\
1971 & 74 & 48 & $24(32.0 \%)$ & 44 \\
1972 & 54 & 32 & $18(33.3 \%)$ & 26 \\
1973 & 47 & 27 & $17(36.2 \%)$ & 9 \\
1974 & 82 & 55 & $22(26.8 \%)$ & 14 \\
\hline Total & 1152 & 715 & $418(36.3 \%)$ & 574 \\
\hline
\end{tabular}

く, 罹病率, L型罹病率, 発病年齡曲線等から見て明ら かで，外来治療制度による癩の管理政策の成果とも云え る。

（2）癩の早期診断，治療促進に及ぼした影響。

表 3 は那覇スキンクリニックで取り扱った, 新発生患 者についての発病から診断迄の年数の統計である。発病 後 1 年以内に治療を開始したものは 13 年間に平均して $45.2 \%$ で，1968年の如きは $57.8 \%$ となっている。此に反 して隔離時代の統計によると，長島愛生園では10)，1 年 
Tab. 3 Duration until First Diagnosis on Leprosy in Naha Skin clinic.

(31 Dec. 1974)

\begin{tabular}{l|c|r|r|l}
\hline Year & $\begin{array}{c}\text { No. of } \\
\text { Newly } \\
\text { detected }\end{array}$ & $\begin{array}{c}\text { Within } \\
\text { one year }\end{array}$ & $\begin{array}{c}\text { Within } \\
\text { Two years }\end{array}$ & $\begin{array}{c}\text { Over } \\
\text { Two years }\end{array}$ \\
\hline 1962 & 11 & $6(54.5 \%)$ & $9(81.8 \%)$ & 2 \\
1963 & 59 & $38(64.4 \%)$ & $51(86.4 \%)$ & 8 \\
1964 & 57 & $28(49.1 \%)$ & $32(56.1 \%)$ & 25 \\
1965 & 80 & $41(51.3 \%)$ & $54(67.5 \%)$ & 26 \\
1966 & 78 & $26(33.3 \%)$ & $35(44.9 \%)$ & 43 \\
1967 & 85 & $33(38.8 \%)$ & $42(49.4 \%)$ & 43 \\
1968 & 90 & $52(57.8 \%)$ & $58(64.4 \%)$ & 32 \\
1969 & 51 & $19(37.3 \%)$ & $25(49.0 \%)$ & 26 \\
1970 & 42 & $20(47.6 \%)$ & $22(52.4 \%)$ & 20 \\
1971 & 48 & $21(43.8 \%)$ & $28(58.3 \%)$ & 20 \\
1972 & 32 & $16(50.0 \%)$ & $20(62.5 \%)$ & 12 \\
1973 & 27 & $9(33.3 \%)$ & $14(51.9 \%)$ & 13 \\
1974 & 55 & $14(25.5 \%)$ & $35(63.6 \%)$ & 20 \\
\hline Total & 175 & $323(45.2 \%)$ & $425(59.4 \%)$ & $290(40.6 \%)$ \\
\hline
\end{tabular}

以内は昭和 6 年で $3.4 \%$ ，昭和 34 年でも $13.9 \%$ と低率で あって, 外来治療制度の方がはるかに早期診断, 治療が 行われやすい事を示している。

（3）退園患者に対する Follow-up の実施。
外来治療のもら一つの利点は, 療養所を退園した患者 （特に L型，B群）の Follow-up を長期間にわたって 行い，再発防止に役立つ事である。WHO は L型，B 群の再発防止のためには, 治療後 Skid Smear が陰性 になっても，さらに10年は治療管理すべきだと勧告して いる6) が，此等の患者を O.P.D で Follow-up する事 は患者自身にとっても, 又社会に対する感染源対策とし ても必要である。現在愛楽園を退園した患者は，自動的 に那覇スキンクリニック，宮古スキンクリニック，又は 八重山保健所の O.P.D に登録され, Follow-up され る事になっている。1962年より1974年迄の愛楽園の退園 者の数は表 2 による 574 名でそのうち418名（72.8\%） を O.P.D で Follow-up している。従って後で再発問 題の項でもふれる様に我々の統計では再発率は一般の O.P.D に比して低い。又 O.P.D の年間の 登録患者の うち退所患者のしめる率は，平均して $36.3 \% ， 1966$ 年の

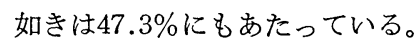

（4）治癒率に及ぼした影響。

此処に云う治癒とは, 臨床的治癒を意味し, 判定は琉 球政府時代の癩対策(6) の規定に従っている。日本の療養 所では臨床的治癒と認められても依然として療養所に在 園し患者として統計にあげられているので，O.P.D で 取扱ら統計とは比較出来ないが，表 4 , 表 5 によると,

Teb. 4 The Status of Out-patients in Naha Skin Clinic.

(March 1975)

\begin{tabular}{l|c|c|c|c|c|c}
\hline Year & $\begin{array}{c}\text { No. of } \\
\text { Registered } \\
\text { patient }\end{array}$ & $\begin{array}{c}\text { No. of } \\
\text { Released } \\
\text { patient }\end{array}$ & $\begin{array}{c}\text { No. of } \\
\text { Died \& } \\
\text { Transfered }\end{array}$ & $\begin{array}{c}\text { No. of } \\
\text { Out-of-control }\end{array}$ & \multicolumn{2}{|c}{ No. of Attendant } \\
\hline 1962 & 14 & 8 & 1 & 4 & $0(0 \%)$ & 1 \\
1963 & 86 & 52 & 10 & 15 & $1(11.1 \%)$ & 8 \\
1964 & 96 & 60 & 6 & 16 & $3(21.4 \%)$ & 11 \\
1965 & 122 & 67 & 10 & 23 & $5(22.7 \%)$ & 17 \\
1966 & 148 & 91 & 11 & 19 & $9(33.3 \%)$ & 18 \\
1967 & 135 & 67 & 12 & 23 & $8(24.2 \%)$ & 25 \\
1968 & 139 & 74 & 11 & 19 & $7(20.0 \%)$ & 28 \\
1969 & 80 & 39 & 8 & 11 & $7(31.8 \%)$ & 15 \\
1970 & 75 & 35 & 3 & 8 & $8(27.6 \%)$ & 21 \\
1971 & 74 & 20 & 6 & 8 & $6(15.6 \%)$ & 34 \\
1972 & 54 & 9 & 4 & 15 & $4(15.4 \%)$ & 22 \\
1973 & 47 & 1 & 5 & 1 & $6(15.0 \%)$ & 34 \\
1974 & 82 & 3 & 11 & 1 & $7(10.4 \%)$ & 60 \\
\hline Total & 1152 & $(45.7 \%)$ & $(8.5 \%)$ & $(14.1 \%)$ & $71(19.5 \%)$ & 294 \\
\hline
\end{tabular}


Tab. 5 The Number of Released Case in Naha Skin Clinic.

(March 1975)

\begin{tabular}{|c|c|c|c|c|c|c|c|c|}
\hline \multirow{2}{*}{ Index case } & \multirow{2}{*}{$\begin{array}{c}\text { Number } \\
\text { of } \\
\text { Registered } \\
\text { pat. }\end{array}$} & \multirow{2}{*}{$\begin{array}{c}\text { Number } \\
\text { of } \\
\text { Released } \\
\text { pat. }\end{array}$} & \multicolumn{2}{|c|}{ Sex } & \multicolumn{4}{|c|}{ Type } \\
\hline & & & M & $\mathrm{F}$ & $\mathrm{L}$ & $\mathrm{T}$ & B & I \\
\hline Newly-detected patient & 747 & $375(50.2 \%)$ & 213 & 162 & $29(7.7 \%)$ & $267(71.2 \%)$ & $17(4.5 \%)$ & $62(16.5 \%)$ \\
\hline Discharged patient & 405 & $151(37.3 \%)$ & 103 & 48 & $43(28.4 \%)$ & $100(66.2 \%)$ & $6(4.0 \%)$ & $2(1.3 \%)$ \\
\hline Total & 1152 & $526(45.7 \%)$ & 316 & 210 & $72(13.7 \%)$ & $367(69.8 \%)$ & $23(4.4 \%)$ & $64(12.1 \%)$ \\
\hline
\end{tabular}

Tab. 6 The Percentage of Released Cases by Leprosy Type in Naha Skin Clinic.

(March 1975)

\begin{tabular}{|c|c|c|c|c|c|c|}
\hline \multirow{2}{*}{\multicolumn{2}{|c|}{ Index Case }} & \multirow{2}{*}{$\begin{array}{l}\text { Number } \\
\text { of } \\
\text { patient }\end{array}$} & \multicolumn{4}{|c|}{ Type } \\
\hline & & & $\mathrm{L}$ & $\mathrm{T}$ & $\mathrm{B}$ & I \\
\hline \multirow{2}{*}{$\begin{array}{l}\text { Newly-detected } \\
\text { patient }\end{array}$} & $\begin{array}{c}\text { Number of Registered } \\
\text { patient }\end{array}$ & 747 & & & & \\
\hline & $\begin{array}{c}\text { Number of Released } \\
\text { patient }\end{array}$ & $\begin{array}{c}375 \\
(50.2 \%)\end{array}$ & $\begin{array}{c}29 \\
(15.4 \%)\end{array}$ & $\begin{array}{c}267 \\
(66.4 \%)\end{array}$ & $\begin{array}{c}17 \\
(19.1 \%)\end{array}$ & $\begin{array}{c}62 \\
(91.2 \%)\end{array}$ \\
\hline \multirow{2}{*}{ Discharged patient } & $\begin{array}{c}\text { Number of Registered } \\
\text { patient }\end{array}$ & 405 & 244 & 139 & 20 & 2 \\
\hline & $\begin{array}{c}\text { Number of Released } \\
\text { patient }\end{array}$ & $\begin{array}{c}151 \\
(37.3 \%)\end{array}$ & $\begin{array}{c}43 \\
(17.6 \%)\end{array}$ & $\begin{array}{c}100 \\
(71.9 \%)\end{array}$ & $\begin{array}{c}6 \\
(30.0 \%)\end{array}$ & $\left(\begin{array}{c}2 \\
(100 \%)\end{array}\right.$ \\
\hline \multirow{2}{*}{ Total } & $\begin{array}{c}\text { Number of Registered } \\
\text { patient }\end{array}$ & 1152 & 432 & 541 & 109 & 70 \\
\hline & $\begin{array}{c}\text { Number of Released } \\
\text { patient }\end{array}$ & $\begin{array}{c}526 \\
(45.7 \%)\end{array}$ & $\begin{array}{c}72 \\
(16.6 \%)\end{array}$ & $\begin{array}{c}367 \\
(67.8 \%)\end{array}$ & $\begin{array}{c}23 \\
(21.1 \%)\end{array}$ & $\begin{array}{c}64 \\
(91.4 \%)\end{array}$ \\
\hline
\end{tabular}

1962 年より那霸 Skin clinic で扱った 1152 名中, 治愈 患者は 526 名 $(45 \cdot 7 \%)$ にあたり，そのうち発病後直ち に O.P.D で治癒した患者（新患者群と略す）では 50.2 $\%$ ，退所患者の Follow-up されている者（退園患者群 と略す）は $37.3 \%$ で，合計して $45.7 \%$ と極めて高い率を 示している。治裣患者のうち $\mathrm{T}$ 型患者がしめる\%は全体 の $69.8 \%$ で，治癒患者の大部分をしめているが，これは O.P.D は T 型の新患者が特に多いからでもある。又 T 型の退園患者 100 名はかって隔離時代に療養所に入園し た者である。全体を通じて治癒率の高いもら一つの理由 は，沖繩では L型が $41 \%{ }^{9}$ と病型学的に T型が多い事 と, L型，B群にしても初期の軽症の多い事に由ると思 われる。退園患者群中 L 型の治癒率が $28.4 \%$ と高いの も，退園時 Skin Smear が陰性ですでに軽快した者が O.P.D でさらに Follow-up されているからである。尚 病型別に治癒率を見ると表 6 に示す如くで，T型， I 群 に高い事がわかり，癩の治療管理は L 型，B群が優先さ れねばならない事がわかる。
（5）再発患者問題。

此処で言う再発 (Relapse) とは, L 型, B 群につい ては, 治療の結果軽快し, 病巣の Skin Smear の菌検 查が一度陰性化し, 再び皮膚に病巣が現われ, Skin Smear で瀬菌が陽性化したものを云い，臨床的に一時 軽快し, Skin Smear の癩菌が減少に止っていたものが 再び増悪した様な Case は Relapse と区別して再燃 (Reactivation) とした。

那覇スキンクリニックで過去13年間に取扱った1152名 の患者の中で, 再発を示した Case は表 7 亿示す如く, 59 名 (5.1\%) で，一般に比して低率である。此のうち 退園患者群は $10.9 \%$ ，新患者群では $2.0 \%$ と低率である のは, 勿論 O.P.D では新患者のL型は原則として取扱 わない事にしているからである。再発患者の大部分は L 型で78\%をしめ，特に退園患者群では全再発患者のうち L型が90.9\%とほとんどをしめているのは退園患者では L型を優先して Follow-up をすべきである事を示して いる。 
Tab. 7 The Number of Relapsed Cases in Naha Skin Clinic.

(March 1975)

\begin{tabular}{|c|c|c|c|c|c|c|c|c|}
\hline \multirow{2}{*}{ Index case } & \multirow{2}{*}{$\begin{array}{l}\text { No. of } \\
\text { Registered } \\
\text { case }\end{array}$} & \multirow{2}{*}{$\begin{array}{l}\text { No. of } \\
\text { Relapsed } \\
\text { case }\end{array}$} & \multicolumn{2}{|c|}{ Sex } & \multicolumn{4}{|c|}{ Type } \\
\hline & & & $\mathrm{M}$ & $\mathrm{F}$ & $\mathrm{L}$ & $\mathrm{T}$ & B & I \\
\hline $\begin{array}{c}\text { Newl-ydetected } \\
\text { patient }\end{array}$ & 747 & $\begin{array}{l}15 \\
(2.0 \%)\end{array}$ & 8 & 7 & $\left(\begin{array}{c}6 \\
(40.0 \%)\end{array}\right.$ & 3 & 5 & 1 \\
\hline $\begin{array}{c}\text { Discharged } \\
\text { patient }\end{array}$ & 405 & $\begin{array}{c}44 \\
(10.9 \%)\end{array}$ & 27 & 17 & $\left(\begin{array}{c}40 \\
(90.9 \%)\end{array}\right.$ & 2 & 2 & 0 \\
\hline Total & 1152 & $\begin{array}{c}59 \\
(5.1 \%)\end{array}$ & 35 & 24 & $\begin{array}{c}46 \\
(78 \%)\end{array}$ & 5 & 7 & 1 \\
\hline
\end{tabular}

Tab. 8 The Percentage of Relapsed Cases by Leprosy Type in Naha Skin clinic.

(March 1975)

\begin{tabular}{|c|c|c|c|c|c|c|}
\hline \multirow{2}{*}{\multicolumn{2}{|c|}{ Index case }} & \multirow{2}{*}{$\begin{array}{l}\text { Number } \\
\text { of } \\
\text { pat. }\end{array}$} & \multicolumn{4}{|c|}{ Type } \\
\hline & & & $\mathrm{L}$ & $\mathrm{T}$ & B & I \\
\hline $\begin{array}{l}\text { Newly-detected } \\
\text { pat. }\end{array}$ & $\begin{array}{l}\text { Number of Registered pat. } \\
\text { Number of Relapsed pat. }\end{array}$ & $\begin{array}{c}747 \\
15 \\
(2.0 \%) \\
\end{array}$ & $\begin{array}{c}181 \\
6 \\
(3.2 \%)\end{array}$ & $\begin{array}{c}402 \\
3 \\
(0.7 \%)\end{array}$ & $\begin{array}{c}89 \\
5 \\
(5.6 \%) \\
\end{array}$ & $\begin{array}{c}68 \\
1 \\
(1.5 \%)\end{array}$ \\
\hline Discharged pat. & $\begin{array}{l}\text { Number of Registred pat. } \\
\text { Number of Relapsed pat. }\end{array}$ & $\begin{array}{c}405 \\
44 \\
(10.9 \%)\end{array}$ & $\begin{array}{c}244 \\
40 \\
(16.4 \%)\end{array}$ & $\begin{array}{c}139 \\
2 \\
(1.4 \%)\end{array}$ & $\begin{array}{c}20 \\
2 \\
(10.0 \%)\end{array}$ & $\begin{array}{c}2 \\
0 \\
(0 \%)\end{array}$ \\
\hline Total & $\begin{array}{l}\text { Number of Registred pat. } \\
\text { Number of Relapsed pat. }\end{array}$ & $\begin{array}{c}1152 \\
59 \\
(5.1 \%)\end{array}$ & $\begin{array}{c}432 \\
46 \\
(10.6 \%)\end{array}$ & $\begin{array}{c}541 \\
5 \\
(0.9 \%)\end{array}$ & $\begin{array}{c}109 \\
7 \\
(6.4 \%)\end{array}$ & $\begin{array}{c}7 \\
1 \\
(1.4 \%)\end{array}$ \\
\hline
\end{tabular}

Tab. 9 The Relationship between Treatment and Relapse on Lepromatous Type in Naha Skin Clinic.

(March 1975)

\begin{tabular}{c|c|c}
\hline Treatment & $\begin{array}{c}\text { No. of Rela- } \\
\text { psed case }\end{array}$ & $\begin{array}{c}\text { Average } \\
\text { Duration of } \\
\text { Treatment (year) }\end{array}$ \\
\hline $\begin{array}{c}\text { Irregular } \\
\text { Treatment } \\
\text { No Treatment }\end{array}$ & 31 & 4.9 \\
\hline Total & 15 & 3.8 \\
\hline
\end{tabular}

療養所を退園した時は少くとも Skin Smear での検 査が陰性か，それに近かった者が，不規則治療や無治療 の結果, 再発すると云う事実は, L 型，B 群は O.P.D でさらに規則治療を厳重に Follow-up されねばならな い事を物語っている。表 8 は再発患者を病型別に，その 割合を見たものであるが， $\mathrm{T}$ 型， I 群に少く，L型， B 群に多い事を示して居り, 此処でも L 型, B群が優先的 に規則的に Follow-up される必要がある。
Tab. 10 The Relationship between Treatment and Relapse on Borderline Group in Naha Skin Clinic.

(March 1975)

\begin{tabular}{c|c|c}
\hline Treatment & $\begin{array}{c}\text { No. of } \\
\text { Relapsed } \\
\text { case }\end{array}$ & $\begin{array}{c}\text { Average } \\
\text { Duration of } \\
\text { Treatment (year) }\end{array}$ \\
\hline $\begin{array}{c}\text { Irregular } \\
\text { Treatment } \\
\text { No Treatment }\end{array}$ & 2 & 3 \\
\hline Total & 5 & 2.2 \\
\hline
\end{tabular}

さらに再発と治療患者との関係を調べたのが表 9 で不 規則治療，無治療を合せ平均約 4 年半で再発を起してい る。尚此処に云う不規則治療とは WHO が定めた治療 率75\%以下のものを云う2。 が，Case が少く結論的な事は云えない。ただ此処に注 目すべき事は，B群には再発，再然と云うよりはむしろ Reaction とも云うべき現象が，治療開始後起る事が案 外にあり，我々の例では規則治療にもかかわらず平均 6 
ケ月以内に $11.9 \%$ に此の現象が起っている。

（6）不規則治療問題。

再発や再燃の原因のほとんどは無治療を含めた不規則 治療の結果で, O.P.D による瀬 Control の成果は, 如 何に不規則治療を低率におさえた治療管理をするかにか かっていると云ってよい。此は又外来治療制度の難しい 点でもあり, 又考え様によっては大きな欠点ともなる。 O.P.D に自発的に来る患者にのみ投薬している様な治 療管理は，真の姿ではない。WHO はどの様によく管 理されている O.P.D でも $10 \%$ の不規則治療患者は常在 すると云っている6)。

此が防止対策として考えられる事は,

1. Home Visitation による治療勧奨

2. Health Education による患者の協力 等があげられる。

著者がすでに別に発表した様に11)，1972年那覇 Skin clinic の不規則治療患者 209 名を at randum に調べた 所， L型 3 名，B群 1 名， I 群 1 名，計 5 名 (2.3\%) に再発を起し，再発患者にはL型が多い事がわかった。 不規則治療の問題でも，WHO の云う如く $10 \%$ 以上 の不規則治療が現実に起るとみて，L型，B群について 優先的に規則治療率を上げていく様にするのが，現実的 な Control 対策と云えよう。

那革 Skin clinic の不規則治療率は表 4 に示す如く平 均 $19.5 \%$ で，年数が長い程率は高くなっている。

（7）接触者家族検診に及ぼす影響。

癩患者の発生を疫学的に検べると, 接触者からの発病 が多い事は学者の一致した意見で，1942 年 Doull は接 触者の発病の危険は一般人に比して $6 \sim 8$ 倍高いと云い 12)，1954 年 Guinto は 8 倍高いと発表している12)。O. P.D では療養所に於けるよりも, Contact Tracing が 行われやすく，患者自身も家族を進んで検診に連れて来 やすい条件がそなわっている。我々は新患者を発見した 場合必ず Contact Tracing を O.P.D で行う事にして いるが，1971年より 1974 年迄に那霸 Skin clinic に於 て実施した成績は 4 年間に 20 名（発見率 $3.0 \%$ ）であっ

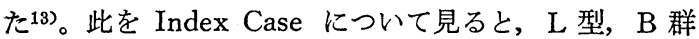
の Contact にのみ限られ， T型， I 群からは出ていな い。此処でも L型，B群の接触者を優先的に Checkす べきである事が強調される。又我々の実施して来た諸々 なる Case-finding program について，方法論的に検討 した結果 Contact Tracing は School Survey, Mass Surveyに比べて一番能率的であった事も証明された ${ }^{13)}$ 。

\section{結 語}

沖繩に於ける癩の外来治療は, 過去13年間実施されて 来たが，此が瀬管理上に及ぼした諸問題を検討すると， 外来治療制度を始めた事によって, 戦後の癩管理の混乱 による多数の在野患者を治療の場に集め, さらに新発生 患者をもすみやかに治療管理し, 現在疫学的に見て, 癩 感染対策に大きな成果をもたらしつつあると云える。即 ち,

1 外来治療制度によって, 癩の早期 発見, 早期 治 療, 退園者の Follow-up, Contact Tracing が積極的 に進められて来た。

2. T型, I 群の治癒率の高い事は, 治療管理 が L 型，B群を優先すべきである事を指唆している。

3. 外来治療制度で特に注意すべき点としてあげられ る事は, 規則治療率を高める事で, 特にL型, B群患者 を優先的に考慮すべきである。

4. 再発は規則的に Follow-up されていない L型, B群患者に多く見られる。

5. 再発防止のためには, 特に退園患者の L 型, B 群 患者を優先的に Follow-up する事が緊要である。

本論文の要旨は昭和 50 年 5 月 16 日岡山市での第 48 回日 本瀨学会で発表し, 尚本研究は笹川記念保健協力財団の 援助を受けた事を深謝いたします。

\section{文献}

1) 八重山保健所：八重山保健所概況，(1970).

2) WHO : Experet Committee on Leprosy, IInd Report. WHO Techn. Rep. Ser. 189, (1960).

3）難波政士, 滝沢 正：琉球に於けるらい対策に 関する調查報告書，琉球政府厚生局，(1960).

4）犀川一夫：琉球政府時代の癞管理（第 1 報）レ プラ, 42巻 3 号, 165-168 (1973).

5）沖繩愛楽園：開園35周年記念誌, (1973).

6) WHO : Expert Committee on Leprosy, 4. Report, WHO Techn. Rep. Ser. 459 (1970).

7）犀川一夫：沖䵷の癩について，西甘本皮膚科， 37 巻 3 号, 339-343 (1975).

8）沖繩愛楽園：開園30周季記念誌，(1968).

9）犀川一夫：沖繩に於ける癩の疫学的研究 第 1 報 レプラ，43巻 1 号, 53-62 (1974).

10）長島愛生園：長島愛生園30年の歩み，(1960).

11）犀川一夫 : 沖繩に於ける攋管理の現状，第 1 報, 医療，27巻 9 号，24-30 (1973).

12) Bechelli, L. M. : A Gide to Leprosy Control, WHO PA 166, 214, Geneva (1966).

13）犀川一夫, 新垣 学: 沖繩に於ける攋管理の現 状，第 2 報，医療30巻，3，215，(1976). 